\title{
FIRST RECORD OF THE RETICULATED DRAGONET, CALLIONYMUS RETICULATUS VALENCIENNES, 1837 (ACTINOPTERYGII: CALLIONYMIFORMES: CALLIONYMIDAE), FROM THE BALEARIC ISLANDS, WESTERN MEDITERRANEAN
}

\author{
Ronald FRICKE $^{1 *}$ and Francesc ORDINES ${ }^{2}$ \\ ${ }^{1}$ Lauda-Königshofen, Germany \\ ${ }^{2}$ Instituto Español de Oceanografia, Centre Oceanogràfic de les Balears, Palma de Mallorca, Spain
}

Fricke R., Ordines F. 2017. First record of the reticulated dragonet, Callionymus reticulatus Valenciennes, 1837 (Actinopterygii: Callionymiformes: Callionymidae), from the Balearic Islands, western Mediterranean. Acta Ichthyol. Piscat. 47 (2): 163-171.

\begin{abstract}
Background. The reticulated dragonet, Callionymus reticulatus, was originally described based on a single specimen, the holotype from Malaga, Spain, south-western Mediterranean, probably collected before 1831. The holotype is now disintegrated; the specific characteristics are no longer discernible. The species was subsequently recorded from several north-eastern Atlantic localities (Western Sahara to central Norway), but missing in the Mediterranean.

Material and methods. Specimens of C. reticulatus were observed and collected during two cruises in 2014 and 2016 in the Balearic Islands off Mallorca and Menorca. The collected specimens ( 8 females) have been deposited in the collection of the Hebrew University of Jerusalem (HUJ).

All individuals of C. reticulatus were collected from beam trawl samples carried out during the DRAGONSAL0914 in September 2014, and during the MEDITS_ES05_16 bottom trawl survey in June 2016, on shelf and slope bottoms around the Balearic Islands. Both surveys used a 'Jennings' beam trawl to sample the epi-benthic communities, which was the main objective of the DRAGONSAL0914 and a complementary objective in the MEDITS_ES05_16. The 'Jennings' beam trawl has a $2 \mathrm{~m}$ horizontal opening, $0.5 \mathrm{~m}$ vertical opening and a $5 \mathrm{~mm}$ diamond mesh in the codend. Trawls had duration of 1 to 3 min of effective sampling (bottom time) at a speed of 2 knots. Catches were sorted out to species and standardized abundances of callionymid species (individuals per $500 \mathrm{~m}^{2}$ ) were obtained by calculating the sampled surface (distance covered $\times$ beam trawl horizontal opening).

Results. Callionymus reticulatus is recorded from the Balearic Islands for the first time; the specimens are described and illustrated.

Conclusions. The new record confirms that the species is still extant in the Mediterranean. A key to Mediterranean callionymid fishes is provided to distinguish $C$. reticulatus from other species of the family in the area. The callionymid fish fauna of the Mediterranean now comprises 11 species, including three Lessepsian migrants originating from the Red Sea.
\end{abstract}

Keywords: dragonets, Spain, Balearic Sea, extended distribution, identification key

\section{INTRODUCTION}

Dragonets (family Callionymidae) are a group of benthic living fishes occurring in the upper 900 metres of all temperate, subtropical, and tropical oceans of the world, and a few species are found in estuarine and freshwater habitats (Fricke 1983a). They are characterised by a depressed body, a triangular head when seen from above, the large eyes, situated dorsally on the head, the presence of a preopercular spine which is bearing additional spinules and/or serrae, the gill opening reduced to a small pore, absent swim bladder, two dorsal fins (the first with thin, flexible spines, the second with soft rays), and jugular pelvic fins which are separated from each other, but each connected with the pectoral-fin base by a membrane. The Atlantic species of the family were revised by Fricke (unpublished ${ }^{* *}$ ), who distinguished 18 valid species-group from the area, including seven species from the western Mediterranean. Nakabo and Hartel (1999) raised Foetorepus dagmarae (Fricke, 1985) and Foetorepus valdiviae (Trunov, 1981) to the species level and described "Foetorepus goodenbeani Nakabo et

\footnotetext{
"Correspondence: Dr Ronald Fricke, Im Ramstal 76, 97922 Lauda-Königshofen, Germany, phone: +49 9343 600801, e-mail: (RF) ronfricke@web.de, (FO) xisco.ordinas@ba.ieo.es.

${ }^{* *}$ Fricke R. 1986. Zoogeographie der Callionymidae (Osteichthyes: Perciformes) des Atlantischen Ozeans. Diploma thesis. Technische Universität Braunschweig, Germany.
} 
Hartel, 1999" (In the present paper assigned to the genus Synchiropus). Fricke (2002), in a checklist of callionymid fishes, listed a worldwide total of 182 valid species in 10 genera. Subsequently, several additional species were described, including Protogrammus alboranensis Fricke, Ordines, Farias et García-Ruiz, 2016 from the Alboran Sea, south-western Mediterranean by Fricke et al. in Farias et al. (2016). "Callionymus sanctaehelenae Fricke, 1983" was synonymised with Callionymus bairdi Jordan, 1888 by Fricke (2002). Synchiropus sechellensis Regan, 1908 was reported as a Lessepsian migrant in the eastern Mediterranean by Gökoğlu et al. (2014), and Diplogrammus randalli Fricke, 1983, another Lessepsian migrant in the eastern Mediterranean, by Seyhan et al. (2017).

During recent surveys of fishes of the northern Balearic Islands in 2014 and 2016, several populations of Callionymus reticulatus Valenciennes, 1837 were discovered, which represent a new record of the species from the island group, and the first record from the Mediterranean since the collection of the holotype from Malaga (Spain) before 1831. Several specimens were collected; they are described in the present paper. The species is compared with allied species, and its distribution is discussed.

\section{MATERIALS AND METHODS}

Materials of Callionymus reticulatus from the Balearic Islands are deposited in the Hebrew University, Jerusalem (HUJ). Counts and measurements followed Hubbs and Lagler (1947), fin-ray counts follow Fricke (1983b); the classification follows Eschmeyer et al. (2017), references according to Fricke (2017), collection acronyms follow Fricke and Eschmeyer (2017). The fish collection of the İzmir Katip Çelebi University, Turkey is abbreviated IKC.

Materials of Callionymus reticulatus from the western Mediterranean (other than the disintegrated holotype) reported in the present paper as new records include the following: HUJ 20569 (4 females), Balearic Islands, Spain, west of Mallorca, south of Dragonera Island, $39^{\circ} 34^{\prime} 26.4^{\prime \prime} \mathrm{N}, 2^{\circ} 19^{\prime} 31.08^{\prime \prime} \mathrm{E}, 46 \mathrm{~m}$ depth, beam trawl, R/V Francisco de Paula Navarro, F. Ordines, Cruise DRAGONSAL0914, St. 34, 10 Sept. 2014. HUJ 20576 (2 females, 13.1-18.7 mm SL), Balearic Islands, Spain, north of Cabrera, $39^{\circ} 13^{\prime} 55.08^{\prime \prime} \mathrm{N}, 2^{\circ} 58^{\prime} 58.62^{\prime \prime} \mathrm{E}-39^{\circ} 13^{\prime} 51.54^{\prime \prime} \mathrm{N}$ $2^{\circ} 59^{\prime} 08.58^{\prime \prime} \mathrm{E}, 57 \mathrm{~m}$ depth, beam trawl, R/V Miguel Oliver, R. Fricke, Cruise MEDITS_ES05_16, St. P1, 8 June 2016, 17:57-18:01 h CEST. HŪJ 20614 (2 females, 16.4-19.7 mm SL), Balearic Islands, Spain, north of Mallorca, 39 $50^{\prime} 49.80^{\prime \prime} \mathrm{N}, 2^{\circ} 44^{\prime} 17.10^{\prime \prime} \mathrm{E}-39^{\circ} 50^{\prime} 52.26^{\prime \prime} \mathrm{N}$, $2^{\circ} 44^{\prime} 22.56^{\prime \prime} \mathrm{E}, 65 \mathrm{~m}$ depth, beam trawl R/V Miguel Oliver, R. Fricke, Cruise MEDITS_ES05_16, 17 June 2016, 09:16-09:18 h CEST.

Comparative materials of $C$. reticulatus and other species in the Mediterranean Sea and the north-eastern Atlantic include the following:

Callionymus fasciatus Valenciennes in Cuvier et Valenciennes, 1837: MNHN A-1529 (holotype, male, 66.2 mm SL), Italy, Sicily; MSNG 37328 (1 male, 59.8 mm SL), Turkey, Bosporus; NMW 35152-35153 (1), Croatia, Split; NMW 61011 (1), Croatia, Crkvenica;
NMW 75983 (2), Croatia, Dalmatia; SMF 5731 (1 female, $66.4 \mathrm{~mm}$ SL), Croatia, Rovinj; ZMB 6099 (1 male, 78.6 mm SL), Italy, Sicily, Messina; ZMB 19969 (1 male, 70.6 mm SL), Croatia, Rovinj; ZMB 19974 (2 males, 77.2-78.2 mm SL), Croatia, Rovinj.

Callionymus filamentosus Valenciennes in Cuvier et Valenciennes, 1837 [Lessepsian migrant]: AMNH 45042 (1 female, $59.6 \mathrm{~mm} \mathrm{SL}$ ), Beirut, Lebanon; AMNH 45449 (4 females, 38.9-48.2 mm SL), Beirut, Lebanon; BMNH 1929.8.31.3 (1), Egypt, Suez Canal, Lake Timsah; BMNH 1939.5.3.25-26 (2), Israel, Haifa; BMNH 1967.2.1.286-287 (2), Lebanon, Beirut; HUJ 6573 (1 male and 4 females, 20.0-101.7 mm SL), Israel, Mediterranean Sea; HUJ 6608 (2 males and 1 female, 33.0-72.7 mm SL), Egypt, northern Sinai, Katib el Galss; HUJ 8067 (2 males and 2 females, 83.0-101.2 mm SL), Israel, Haifa; HUJ 8076 (1 male and 4 females, 60.8-80.0 mm SL), Israel, Rubin; HUJ 8080 (1 male, 82.0 mm SL), Israel, Rubin; HUJ 8083 (1 male, 108.5 mm SL), Israel, Rubin; HUJ 8085 (3 females, 69.7-84.3 mm SL), Israel, Haifa; HUJ 8090 (1 male and 4 females, 61.3-78.2 mm SL), Israel, Haifa; HUJ 8093 (1 male, 93.8 mm SL), Israel, Haifa; HUJ 8094 (6 females, 60.6-80.4 mm SL), Gaza, Khan Yunis; HUJ 8096 (6 males and 3 females, 64.0$100.0 \mathrm{~mm}$ SL), Israel, Mediterranean Sea; HUJ 8097 (4 females, 7.8-57.3 mm SL), Israel, Mediterranean Sea; HUJ 10405 (2 males, 78.0-87.1 mm SL), Israel, Yafo; HUJ 10539 (4, 70.0-71.0 mm SL), Gaza; MSNG 41341 (1 female), Israel, Mediterranean Sea; SMNHTAU 4701 (1 male and 1 female, 94.1-106.0 mm SL), Egypt, northern Sinai; SMNHTAU 5389 (28, 47.8-97.6 mm SL), Israel, Mediterranean Sea; SMNHTAU 5406 (2 males, 82.0-85.0 mm SL), Israel, Ashkelon; SMNHTAU 5922 (2 males, 65.9-67.9 mm SL), Israel, Haifa; SMNHTAU 4700 (3, 86.0-108.6 mm SL), Egypt, northern Sinai; SMNS 8566 (10), Lebanon, Beirut; SMNS 9066 (3), Gaza; SMNS 9067 (1), Gaza; SMNS 23060 (1), Cyprus, Cape Greco; USNM 232251 (2 females, 51.1-51.8 mm SL), Lebanon, Beirut; USNM 232251 (1546.3-79.0 mm SL), Lebanon, Beirut; USNM 232257 (3 males, 68.3$72.5 \mathrm{~mm} \mathrm{SL}$ ), Lebanon, Beirut.

Callionymus lyra Linnaeus, 1758: AMNH 1187 (1); AMNH 8775 (1); BMNH 1896.5.20.24-26 (3), Spain, Galicia, Ría de Arosa; BMNH 1971.7.21.174-177 (4), Portugal, Sezimbra Bay; BMNH 1974.9.30.26 (1), UK, Shetland Islands; BMNH 1981.9.22.72-74 (3), Ireland, Galway Bay; BMNH uncat. (1), UK, River Thames; IRSN 390 (1), Western Sahara, Baie de Caballo; IRSN 7405 (1), Western Sahara, Rio de Oro; SMNS 44(1), France, Dieppe; SMNS 8430 (5), UK, East Surrey; SMNS 8530 (3), UK, Kent; SMNS 8534 (13), Germany, Helgoland Island; SMNS 8535 (9), Germany, Helgoland Island; SMNS 8902 (1), Germany, Helgoland Island; SMNS 9641 (3), Netherlands, Texel; SMNS 9650 (4), Netherlands, Texel; SMNS 9700 (2), Netherlands, Texel; SMNS 11560 (1), France, Bretagne; SMNS 13594 (1), 
France, Medoc; SMNS 13872 (2), France, Île d'Yeu; SMNS 13873 (2), France, Île d'Yeu; SMNS 17898 (6), Germany, Schleswig-Holstein; SMNS 20038 (1), Germany, Bremen, Weser River; SMNS 20046 (1), Germany, west of Scharhörn; SMNS 20049 (14), Germany, Niedersachsen; SMNS 23239 (7), Germany, Schleswig-Holstein; SMNS 23305 (4), Germany, Niedersachsen; SMNS 23309 (18), Germany, Niedersachsen; SMNS 23315 (5), Germany, Niedersachsen; SMNS 23323 (22), Germany, Niedersachsen; SMNS 23464 (3), Portugal, Rio Douro; SMNS 23465 (2), Portugal, Rio Tejo; SMNS 23466 (2), Portugal, Rio Tejo; SMNS 24464 (2), Denmark, Skagerrak; SMNS 25823 (1), Italy, Venice; SMNS 26407 (2), Germany, Wadden Sea; TMN 546 (1), Norway, Lofoten; ZMB 4940 (1), Sweden, Bohuslän; ZMB 21968 (2), France, Bay of Biscay.

Callionymus maculatus Rafinesque, 1810: BMNH 1845.6.22.214-215 (2), Adriatic Sea; BMNH 1866.12.3.1-2 (2), UK, Shetland Islands; BMNH 1868.9.9.4 (1), UK, Shetland Islands; BMNH 1887.4.23.16 (1), UK, Scotland; BMNH 1888.4.3.16 (1), UK, Scotland; BMNH 1888.4.3.17-19 (3), UK, Scotland; BMNH 1962.7.30.630 (1), Isle of Man; BMNH 1963.5.14.459-460 (2), France, Banyulssur-Mer; BMNH 1970.2.17.443-453 (11), Ireland, Mizzen Head; BMNH 1972.1.26.80 (1), Rockall Trough; BMNH 1979.7.25.1 (1), UK, Scotland; BMNH 1983.3.8.246-249 (4), UK, Plymouth; HUJ 8081 (12), Israel, Ashkelon; HUJ 20611 (1), Balearic Islands, northeast of Mallorca; HUJ 20629 (3), Balearic Islands, northwest of Menorca; HUJ 20634 (2), Balearic Islands, northeast of Mallorca; HUJ 20636 (1), Balearic Islands, northeast of Mallorca; IFAN 195412 (1), Algeria; IRSN 294 (2), Iceland; IRSN 8321 (2), France, Banyuls-sur-Mer; MNHN 1977-0150 (10), France, Sète; MSNG 32412 (1), Italy, Genova; SMNS 571 (2), Croatia, Split; SMNS 992 (4), Italy, Trieste; SMNS 8497 (2), Italy, Genova; SMNS 8511 (33), Italy, Genova; SMNS 8526 (1), UK, Scotland; SMNS 21188 (1), Italy, Genova; SMNS 24064 (1), Denmark, Jutland; SMNS 24097 (1), Denmark, Jutland; SMNS 24098 (23), Germany, Niedersachsen; SMNS 24468 (2), Denmark, Skagerrak; SMNS 26412 (2), Germany, Wadden Sea; TMN 774 (1), Norway, Tosen; ZMB 2162 (2), Mediterranean Sea; ZMB 12402 (1), France, Nice.

Callionymus pusillus Delaroche, 1809: MNHN A1525 (2 syntypes), Baleares Islands, Ibiza; MNHN A1520 (1), France, Nice; NMW 21124 (1), Adriatic Sea; NMW 31080 (1), Italy, Rome; NMW 31081 (1), France, Nice; NMW 31082 (1), Croatia, Hvar; NMW 59750 (12), Croatia, Split; NMW uncat. (1), Bulgaria, Varna; NMW uncat. (2), Italy, Sardinia; NMW uncat. (1), Spain, Barcelona; NMW uncat. (6), Portugal, Lisboa; SMNS 2212 (7), Italy, Naples; SMNS 3253 (2), Italy, Naples; SMNS 8477 (2), Turkey, Muğla; SMNS 8480 (6), Spain, Mallorca;
SMNS 8481 (7), Spain, Mallorca; SMNS 9368 (2), Spain, Menorca; SMNS 9429 (2), Croatia, Cres Island; SMNS 11527 (1), Turkey, Muğla; SMNS 12401 (1), Spain, Formentera Island; SMNS 12415 (2), Spain, Formentera Island; SMNS 12461 (1), Spain, Formentera Island; SMNS 12543 (3), France, Pyrenées Orientales; SMNS 13595 (1), Croatia, Istria; SMNS 13596 (1), Turkey, Istanbul, Black Sea; SMNS 13598 (4), Italy, Elba Island; SMNS 13599 (2), Greece, Peloponnese; SMNS 13600 (1), Turkey, Balıkesir; SMNS 19201 (2), Italy, Giglio Island; SMNS 20592 (4), Italy, Elba Island; SMNS 24497 (4), Italy, Elba Island; SMNS 24900 (1), Malta, Cirkewwa; ZMB 22274 (1), Bulgaria; ZMB 22897 (1), Italy; Napoli.

Callionymus reticulatus Valenciennes in Cuvier et Valenciennes, 1837: MNHN A-1528 (holotype, nearly completely disintegrated when examined on 16 Oct. 1981 by RF), Málaga, Spain; BMNH 1850.11.11.1 (1), UK, mouth of River Thames; BMNH 1951.2.19.5152 (2), UK, English Channel; BMNH 1951.2.19.54 (1), UK, English Channel; BMNH 1960.3.1.32 (1), Isle of Man; BMNH 1961.10.30.421 (1), UK, Norfolk; BMNH 1962.7.30.640 (1), Isle of Man; BMNH 1962.7.30.641 (1), Isle of Man; BMNH 1962.7.30.642 (1), Isle of Man; BMNH 1962.7.30.643 (1), Isle of Man; BMNH 1971.10.22.39-43 (5), Netherlands, 52 $2^{\circ} 34^{\prime}-$ $53^{\circ} 32^{\prime} \mathrm{N}, 03^{\circ} 33^{\prime}-05^{\circ} 25^{\prime} \mathrm{E}$; IEOV uncat. (7), Spain, Galicia, Ría de Arosa; IRSN 13622 (1), Western Sahara, Cap Blanc; SMNS 20645 (1), Faial Island, Azores; SMNS 24091 (1), Denmark, west of Jutland; SMNS 24092 (1), Denmark, west of Jutland; SMNS 24093 (1), Denmark, west of Jutland; SMNS 24094 (31), Germany, Ostfriesland; SMNS 24095 (29), Germany, Ostfriesland; SMNS 24096 (1), Denmark, west of Jutland; SMNS 24099 (5), Germany, Ostfriesland; SMNS 24100 (70), Germany, Ostfriesland; SMNS 24101 (7), Germany, Ostfriesland; SMNS24102(12), Germany, Ostfriesland;SMNS24103 (67), Germany, Ostfriesland; SMNS 24106 (41), Germany, Ostfriesland; SMNS 24107 (24), Germany, Ostfriesland; SMNS 24108 (28), Germany, Ostfriesland; SMNS 24109 (5), Germany, Ostfriesland; SMNS $24110 \quad$ (19), Germany, Ostfriesland; SMNS 24111 (25), Germany, Ostfriesland; SMNS 26396 (1), Germany, off Husum, SchleswigHolstein; SMNS 26397 (3), Germany, off Husum, Schleswig-Holstein; SMNS 26403 (9), Germany, off Husum, Schleswig-Holstein; UBZM 173 (1), Norway, Sunnfjord; UBZM 377 (1), Norway, Osterfjord; UBZM 8110 (1), Norway, Mefjordbøen.

Callionymus risso LeSueur, 1814: BMNH 1891.8.31.18 (1), Italy, Calabria; BMNH 1963.7.25.70-72 (3), Romania; BMNH 1980.7.9.33-34 (2), Mediterranean Sea; CAS-SU 20920 (14), Italy, Napoli; HUJ 7205 (2), Turkey; HUJ 8082 (7), Israel; HUJ 8176 (1), Egypt, El-Arish; MNHN A1540-A1544 (5 syntypes), France, Nice; MNHN A1545 (2), Italy, Napoli; 
NMW 35140 (5), Italy, Sicily, Palermo; NMW 58740 (2), Croatia, Adriatic Sea; NMW 79770 (4), Croatia, Isola; NMW 89051 (2), Croatia, Split; SMF 8328 (1), Turkey, Marmara Sea; SMNS 582 (1), France, Nice; SMNS 13597 (1), Turkey, Balıkesir; SMNS 13601 (3), Italy, Elba Island; SMNS 13602 (1), Greece, Peloponnes; SMNS 13603 (1), Turkey, Muğla; SMNS 16085 (1), Croatia, Cres Island; SMNS 24338 (1), Croatia, Cres Island; TAU P.4703 (11), Egypt, off northern Sinai; ZMB 10997 (1), Italy, Ravenna; ZMB 13337 (3), Turkey; ZMB 21488 (3), Romania; ZMUC P.64152 (3), Tunisia; ZMUC P.64153 (1), Tunisia.

Diplogrammus randalli Fricke, 1983 [Lessepsian migrant]: IKC PIS.1089 (1), Turkey, Muğla Province, Fethiye.

Protogrammus alboranensis Fricke, Ordines, Farias et García-Ruiz, 2016: CFM_IEOMA 5557 (holotype, male, $50.2 \mathrm{~mm} \mathrm{SL}$ ), Spain, Alboran Sea, $35^{\circ} 56^{\prime} 36^{\prime \prime} \mathrm{N}, \quad 3^{\circ} 05^{\prime} 55^{\prime \prime} \mathrm{W}$; CFM_IEOMA 5558 (1 paratype, male, $48.1 \mathrm{~mm} \mathrm{SL}$, same data as the holotype); SMF 35715 (1 paratype, male, $36.5 \mathrm{~mm} \mathrm{SL}$ ), Spain, Alboran Sea, 35 $56^{\prime} 19^{\prime \prime} N$, 305'48' 'W; SMF 35716 (1 paratype, female, $24.5 \mathrm{~mm} \mathrm{SL}$, same data as SMF 35715).

Protogrammus sousai (Maul, 1972): MMF 22877 (holotype), Great Meteor Seamount, 315-320 m depth; MMF 22389 (1 paratype), Great Meteor Seamount, $310 \mathrm{~m}$ depth; MMF 22843a (1 paratype), Great Meteor Seamount; MMF 22843b (1 paratype), Great Meteor Seamount.

Synchiropus phaeton (Günther, 1861): ANSP 1994519956 (12 syntypes of Callionymus festivus Bonaparte, 1833 and Callionymus phaeton Günther, 1861), Mediterranean Sea; NMW 58817 (1 syntype of Callionymus phaeton Günther, 1861), Mediterranean Sea; BMNH 1971.7.21.171-173 3), Portugal; BMNH 1972.1.10.66-71 (6), Morocco; HUJ 8077 (3), Israel; HUJ 8079 (2), Israel; HJ 8092 (5), Israel; HUJ 8397 (1), Israel; HUJ 20633 (1), Balearic Islands, northeast of Mallorca; SMNS 15282 (1), France, Pyrenées Orientales.

Synchiropus sechellensis (Regan, 1908) [Lessepsian migrant]: MFFAU 117 (1 male, $82 \mathrm{~mm}$ SL), Turkey, Gulf of Antalya.

\section{RESULTS}

\section{Family CALLIONYMIDAE \\ Callionymus Linnaeus, 1758 \\ Callionymus reticulatus Valenciennes in Cuvier et Valenciennes, 1837 \\ Fig. 1, Table 1}

Description. Dorsal-fin spines IV, rays ix, 1; anal-fin rays vii-ix, 1. Head slightly depressed, 3.5-4.1 in SL. Eye 2.23.1 in head length. Branchial opening pore-like, dorsal in position. Preopercular spine with a small, upcurved main tip and two points at its dorsal margin, formula:

$$
-\frac{2}{-} 1
$$

(Fig. 1). First dorsal fin without a filament, first spine shorter than first ray of second dorsal fin in females; caudal fin rounded, without filaments, caudal-fin length 3.7-5.2 in SL. Measurements of the voucher specimens from the Balearic Islands see Table 1.

Colour of fresh, female specimens: body above lateral line cream, back with six dark saddle-like areas, surrounded by white spots, lower sides of body white; upper half of pectoral-fin base with dark grey blotch, lower half with two white spots; eye dark grey. First dorsal mostly dark grey, membranes ventrally pale; second dorsal translucent, with oblique rows of dark blotches, membranes with a distal dark grey margin. Anal fin with a narrow distal dark band. Pectoral fins translucent; pelvic fins pale, with two series of dark grey blotches. Caudal fin pale, with three series of dark grey blotches.

\section{DISCUSSION}

This species was first described by Valenciennes in Cuvier and Valenciennes (1837a: 284) based on a single specimen from Malaga, Spain. The species was first confused by several authors with Callionymus maculatus Rafinesque, 1810 (Day 1881: 177-178, part: UK; Moreau 1881: 169-170, part: France; de Buen 1935: 140, Spain; Nobre 1935: 153, 505, Portugal; Albuquerque 1954-1956: 838, Portugal). Chang (1951: 297, pls. 1-3) re-established the species, distinguished it from $C$. maculatus, and reviewed the distribution; subsequently, the species was reported from various localities in the north-eastern Atlantic between Portugal and Norway (Wheeler 1961: 753, Isle of Man; mouth of Thames River, UK, North Sea; Boer 1966: 261, Netherlands; Ryland 1969: 129, Ireland; Wheeler 1969: 432, western Channel, Irish Sea, southern North Sea; Boer 1971: 506, Netherlands; Demir 1972: 997, Plymouth, UK; Wheeler 1973: 517, checklist; Wheeler et al. 1975: 197, Irish Sea; Fröiland and Greve 1976: 1, Norway; Zander 1979: 414, Helgoland, Germany; Iglesias 1981: 201, 203, northern Spain; Santos et al. 1997: 128, Azores; Quéro et al. 2003: 277, Ile d'Oléron, France; Neudecker and Damm 2004: 204, Germany, North Sea; le Mao 2009: 79, Guernsey, English Channel; Quéro et al. 2009: 939, Ile d'Yeu, France; da Cunha and Antunes 2012: 489, Estoril, Portugal). Fricke (1982: 65) treated the species as valid in an initial checklist of callionymid fishes; Fricke et al. (1984: 107) reported the disintegrated state of the holotype in a type catalogue. Fricke (unpublished*) revised the species and recorded it from a distribution range from western Sahara to Norway, and Malaga in the western Mediterranean based on the holotype; the status of the species was summarised by Fricke in Whitehead et al. (1986: 1090), Fricke (1987: 1006; 2002: 38; 2016: 2819). In the western Mediterranean, the species was previously only known from the holotype from Malaga, 


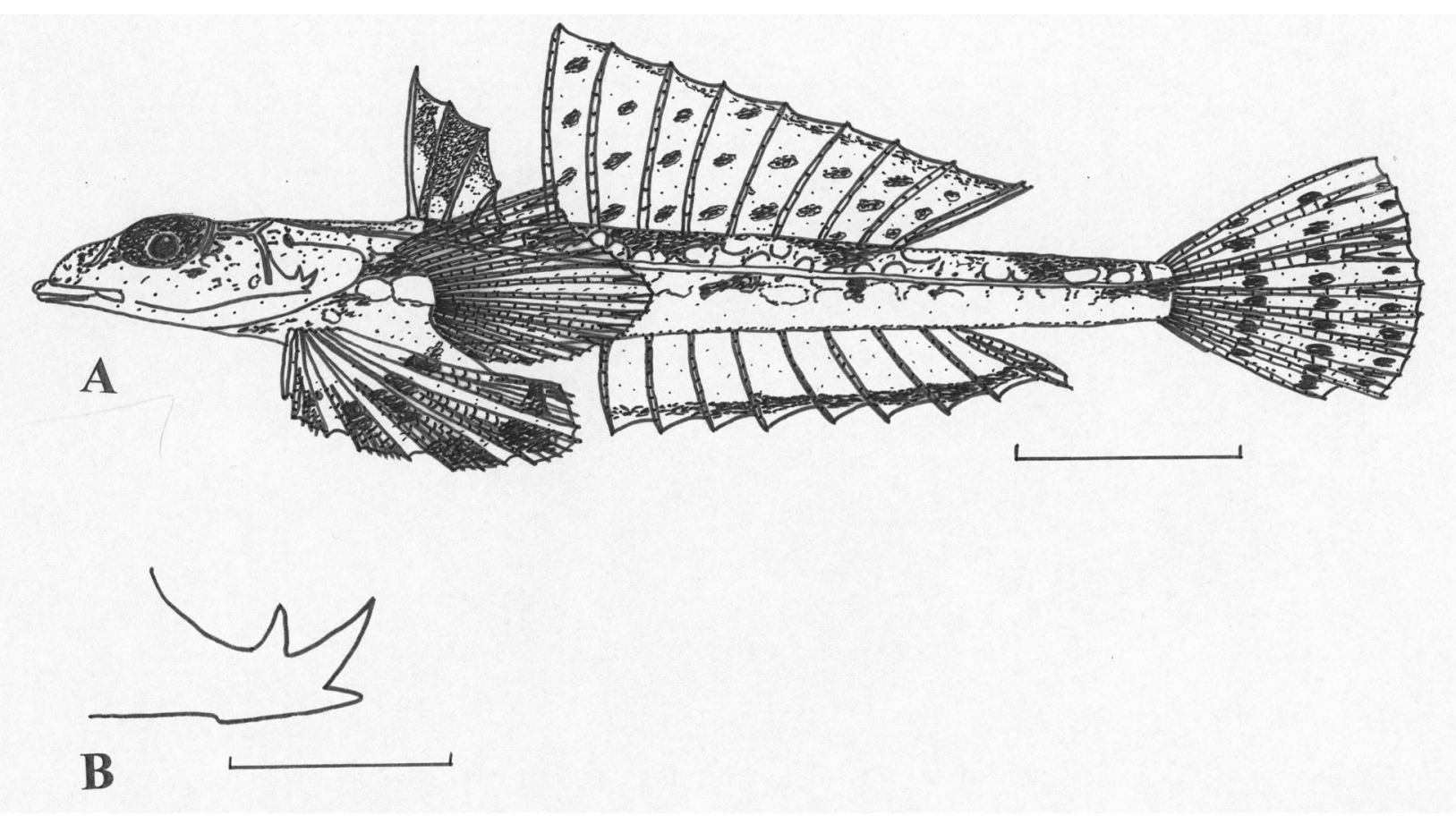

Fig. 1. Callionymus reticulatus, HUJ 20569, specimen 1, female, $25.2 \mathrm{~mm} \mathrm{SL}$, western Mediterranean Sea, Spain, Balearic Islands, west of Mallorca, south of Dragonera Island; A. Lateral view; scale indicates $5 \mathrm{~mm}$. B. Left preopercular spine; scale indicates $1 \mathrm{~mm}$

Table 1

Callionymus reticulatus Valenciennes, 1837; Measurements of specimens from Mallorca

\begin{tabular}{|c|c|c|c|c|c|c|}
\hline \multirow{3}{*}{ Parameter } & \multicolumn{6}{|c|}{ Specimen (museum number and sex) } \\
\hline & \multicolumn{4}{|c|}{ HUJ 20569} & \multicolumn{2}{|c|}{20614 HUJ } \\
\hline & Female & Female & Female & Female & Female & Female \\
\hline Standard length & 25.2 & 24.3 & 20.9 & 17.0 & 19.7 & 16.4 \\
\hline Caudal-fin length & 5.7 & 5.8 & 5.7 & 3.7 & 3.8 & 3.4 \\
\hline Predorsal (1) length & 7.6 & 6.8 & 6.4 & 6.4 & 7.0 & 6.4 \\
\hline Predorsal (2) length & 10.9 & 11.2 & 9.2 & 8.0 & 9.8 & 7.9 \\
\hline Preanal length & 11.9 & 13.7 & 10.7 & 8.8 & 11.2 & 8.6 \\
\hline Prepelvic fin length & 6.5 & 5.1 & 5.6 & 4.7 & 4.9 & 4.4 \\
\hline Prepectoral fin length & 9.2 & 8.9 & 6.9 & 5.8 & 7.0 & 5.7 \\
\hline Head length & 6.6 & 6.9 & 5.7 & 4.5 & 5.4 & 4.0 \\
\hline Body depth & 2.2 & 1.9 & 1.8 & 1.4 & 2.2 & 2.1 \\
\hline Body width & 4.0 & 3.9 & 2.4 & 2.2 & 3.9 & 3.2 \\
\hline Orbit diameter & 2.4 & 2.4 & 2.1 & 2.1 & 1.9 & 1.7 \\
\hline Preorbital length & 1.6 & 1.4 & 1.3 & 1.3 & 1.3 & 1.2 \\
\hline Bony interorbital & 0.5 & 0.5 & 0.4 & 0.3 & 0.4 & 0.3 \\
\hline Caudal peduncle length & 5.3 & 4.4 & 4.9 & 3.2 & 3.5 & 3.6 \\
\hline Caudal peduncle depth & 1.3 & 1.2 & 1.1 & 0.8 & 0.9 & 0.8 \\
\hline Upper-jaw length & 2.1 & 2.4 & 2.2 & 2.0 & 1.8 & 1.6 \\
\hline Length of first spine of first dorsal fin & 2.8 & 3.4 & 2.1 & 1.8 & 2.2 & 1.9 \\
\hline Length of first ray of second dorsal fin & 3.6 & 4.9 & 2.9 & 2.5 & 3.0 & 2.4 \\
\hline Length of last ray of second dorsal fin & 1.9 & 2.5 & 2.2 & 1.7 & 1.9 & 1.8 \\
\hline Length of first anal-fin ray & 2.5 & 2.9 & 1.8 & 1.6 & 1.8 & 1.6 \\
\hline Length of last anal-fin ray & 2.6 & 3.1 & 2.2 & 2.4 & 2.5 & 2.3 \\
\hline Pectoral-fin length & 4.9 & 5.0 & 3.9 & 3.2 & 4.1 & 3.5 \\
\hline Pelvic-fin length & 6.3 & 6.8 & 5.6 & 3.7 & 4.8 & 4.2 \\
\hline
\end{tabular}


Spain, which had been collected by Louis-AntoineFrançois Baillon (see Bauchot et al. 1990: 57), probably before 1831 . The currently known distribution records of the species are summarized in Fig. 2.

In the course of the DRAGONSAL 2014 Cruise in the Balearic Islands, numerous specimens of Callionymus reticulatus were observed south and west of Mallorca but not retained (see Table 2, Fig. 3); just 4 small females collected at station 34 are available for this study. While the species appeared to be very common in September 2014, it was scarcely found at the stations with the previously highest abundance during the MEDITS_ES05 Cruise in June 2016. The reason of the disappearance from many stations remains unknown. Seasonal migrations for spawning or feeding could be one explanation for such differences. According to Fricke in Whitehead et al. (1986: 1090) the species reproduces in March-June in the North Sea. If spawning takes place at the same period in the Mediterranean and it involves some migration to other areas this could be the explanation for such a scarcity of individuals.

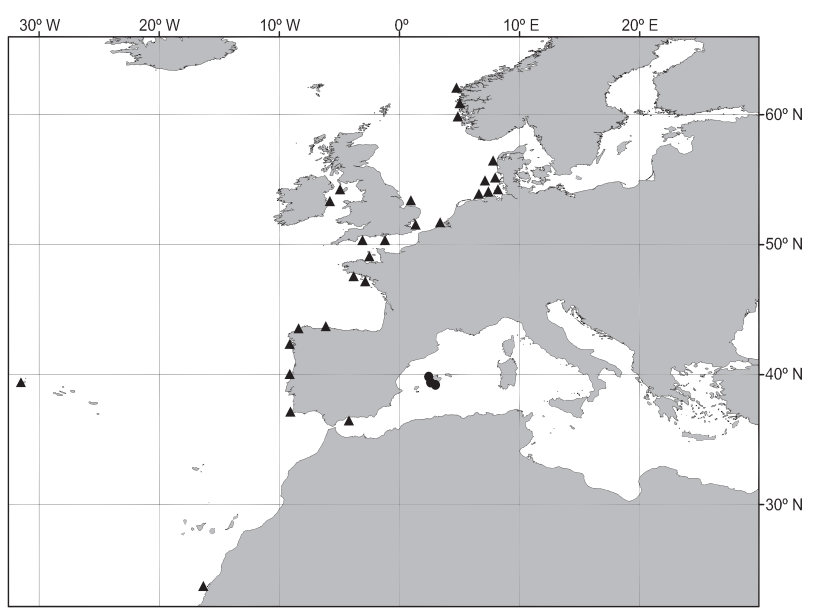

Fig. 2. Geographical distribution of Callionymus reticulatus in the north-eastern Atlantic and Mediterranean; Circles are new records from the Baleares, triangles are previous records
The new record of Callionymus reticulatus from the Balearic Islands confirms that this species is extant in the Mediterranean Sea, and expands the known distribution range by 700 kilometres towards the northeast into the Mediterranean; this is the second Mediterranean region for which the presence of this otherwise Atlantic species could be confirmed. A total of 10 species of callionymid fishes is now known to occur in the Mediterranean Sea, including two Lessepsian immigrants of Red Sea origin which have invaded through the Suez Canal.

Callionymus reticulatus inhabits coarse sand bottom, with a grain size similar to the size of the spots on the back and sides of the specimens; the species was found near Mallorca at depths of 46-68 m, significantly deeper than in the north-eastern Atlantic; Atlantic depth records based on SMNS materials range from 11-57 m. A reason for this deeper occurrence may be due to a slightly higher water temperature in the Mediterranean compared to the same depths in the north-eastern Atlantic and the presence of red algae communities such as maërl and Peyssonnelia beds which dominate the coarse sand circalittoral bottoms of the Balearic Islands down to $80 \mathrm{~m}$ depth (Ballesteros 1994, Ordines and Massutí 2009, Barberá et al. 2012). In this sense, there seems to be a clear habitat partitioning between $C$. reticulatus and $C$. maculatus in the area sampled during the DRAGONSAL0914 survey. Callionymus reticulatus showed high abundances that decreased with depth until it disappeared deeper than 68 $\mathrm{m}$, whereas $C$. maculatus begun to appear at $78 \mathrm{~m}$ depth (Fig. 4), in coincidence with the disappearance of red algae beds and the beginning of bare sandy-mud bottoms. The red algae beds of the south west of Mallorca seem to play a key role to juvenile and small fish species, which show their highest abundances in these bottoms. Both, shelter availability, due to the higher structural complexity of these beds compared to bare sandy mud bottoms, and feeding opportunities, they show high abundances of small invertebrates as well, seem to be the main traits explaining juvenile and small fish preferences for these habitats (Ordines et al. 2011). The population of C. reticulatus in the Balearic Islands seems to be positively affected by these habitats as well.

Table 2

Callionymus reticulatus Valenciennes, 1837; Stations near Mallorca where the species was observed during the DRAGONSAL 2014 Cruise

\begin{tabular}{ccccc}
\hline Station No. & Date & Region & Geographical coordinates & Depth [m] \\
\hline 4 & 03 Sep 2014 & South of Mallorca & $39^{\circ} 25^{\prime} 46.92^{\prime \prime} \mathrm{N} 2^{\circ} 37^{\prime} 41.52^{\prime \prime} \mathrm{E}$ & 59 \\
17 & 06 Sep 2014 & South of Mallorca & $39^{\circ} 18^{\prime} 58.32^{\prime \prime} \mathrm{N} 2^{\circ} 49^{\prime} 19.20^{\prime \prime} \mathrm{E}$ & 47 \\
19 & 06 Sep 2014 & South of Mallorca & $39^{\circ} 18^{\prime} 00.00^{\prime \prime} \mathrm{N} 2^{\circ} 56^{\prime} 43.80^{\prime \prime} \mathrm{E}$ & 48 \\
21 & 07 Sep 2014 & South of Mallorca & $39^{\circ} 16^{\prime} 59.52^{\prime \prime} \mathrm{N} 2^{\circ} 58^{\prime} 13.08^{\prime \prime} \mathrm{E}$ & 49 \\
26 & 08 Sep 2014 & South of Mallorca & $39^{\circ} 14^{\prime} 19.68^{\prime \prime} \mathrm{N} 2^{\circ} 56^{\prime} 55.68^{\prime \prime} \mathrm{E}$ & 68 \\
34 & 10 Sep 2014 & West of Mallorca & $39^{\circ} 34^{\prime} 26.40^{\prime \prime} \mathrm{N} \mathrm{2} 2^{\circ} 19^{\prime} 31.08^{\prime \prime} \mathrm{E}$ & 46 \\
47 & 12 Sep 2014 & South of Mallorca & $39^{\circ} 22^{\prime} 01.20^{\prime \prime} \mathrm{N} 2^{\circ} 41^{\prime} 04.20^{\prime \prime} \mathrm{E}$ & 52 \\
53 & 14 Sep 2014 & South of Mallorca & $39^{\circ} 21^{\prime} 29.88^{\prime \prime} \mathrm{N} 2^{\circ} 41^{\prime} 37.32^{\prime \prime} \mathrm{E}$ & 52 \\
55 & 14 Sep 2014 & South of Mallorca & $39^{\circ} 21^{\prime} 20.52^{\prime \prime} \mathrm{N} \mathrm{2} 2^{\circ} 41^{\prime} 55.32^{\prime \prime} \mathrm{E}$ & 50 \\
56 & 14 Sep 2014 & South of Mallorca & $39^{\circ} 22^{\prime} 19.20^{\prime \prime} \mathrm{N} \mathrm{2} 2^{\circ} 42^{\prime} 34.92^{\prime \prime} \mathrm{E}$ & 47 \\
61 & 15 Sep 2014 & South of Mallorca & $39^{\circ} 22^{\prime} 01.92^{\prime \prime} \mathrm{N} \mathrm{2} 2^{\circ} 42^{\prime} 03.60^{\prime \prime} \mathrm{E}$ & 54 \\
\hline
\end{tabular}




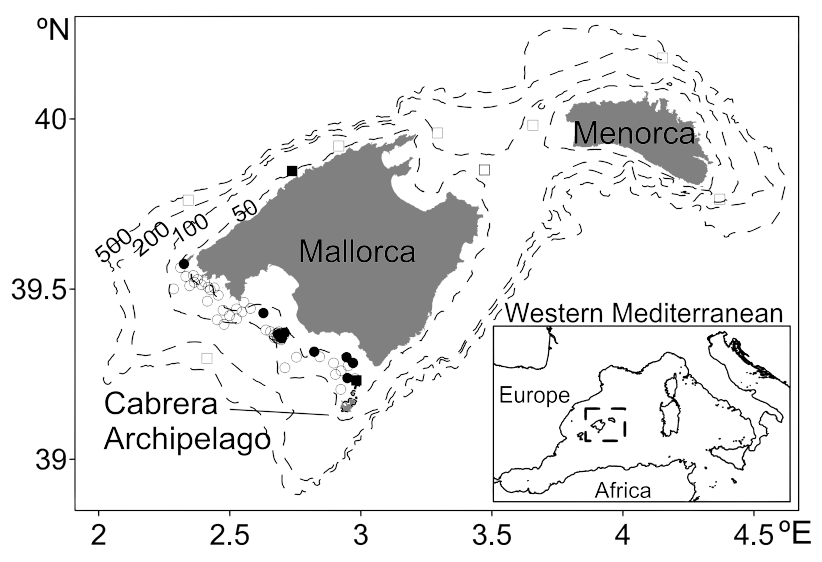

Fig. 3. Map of the study area. Circles represent the 57 beam trawl stations sampled during DRAGONSAL0914 which took place in the south west shallow shelf off Mallorca Island; Squares represent the 13 beam trawl stations sampled during MEDITS_ES05_16, which were located on the shelf and upper slope off Mallorca and Menorca; Black circles and squares represent samples at which Callionymus reticulatus appeared; The 50,100, 200, and $500 \mathrm{~m}$ isobaths are shown

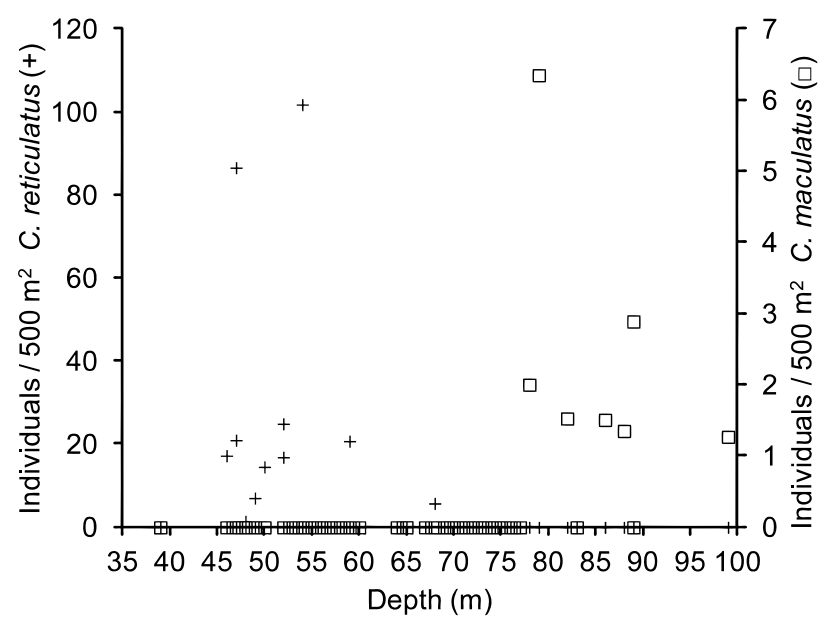

Fig. 4. Standardized abundance by depth for Callionymus reticulatus and $C$. maculatus (left and right $\mathrm{Y}$ axes, respectively) in the south west off Mallorca; The abundances were calculated from the samples collected during the DRAGONSAL0914 beam trawl survey

\section{KEY TO SPECIES OF CALLIONYMIDAE FROM THE MEDITERRANEAN SEA}

1a. Second dorsal rays all branched (occasionally except for the first); gill opening sublateral .. 2

1b. Second dorsal rays not all branched (only the last is divided at the base); gill opening dorsal .................. 3

2a. Caudal fin with two median filaments; first dorsal fin without filaments Synchiropus phaeton 2b. Caudal fin without median filaments; first dorsal fin with 4 (male) or 1 (female) filaments...... Synchiropus sechellensis

3a. Opercle distally with a free flap of skin (which may be present only in the lower half); sides of body with a ventrolateral fold of skin (which may be complete or divided into segments) .......................................... 4

3b. Opercle distally without a free flap of skin; sides of body without a ventrolateral fold of skin .. 5

4a. Only lower half of opercle with a free flap of skin; sides of body with a ventrolateral fold of skin which is divided into segments; preopercular spine with a single dorsal point (additional to the main tip and an antrorse spine at base); second dorsal fin with 9 rays; anal fin with 8 rays ........ Protogrammus alboranensis

4b. Complete opercle with a distal free flap of skin; sides of body with an undivided ventrolateral fold of skin; preopercular spine with 3-7 dorsal points (additional to the main tip and an antrorse spine at base); second dorsal fin with 7-8 rays; anal fin with 6-7 rays

Diplogrammus randalli

5a. Preopercular spine with 4-7 antrorse serrae at its upper side; male: first spine of first dorsal fin detached from rest of fin Callionymus filamentosus

5b. Preopercular spine with 1-3 moderately curved points at its upper side; male: first spine of first dorsal fin connected with second spine by a membrane

.. 6

6a. First dorsal with III spines Callionymus risso

6b. First dorsal with IV spines 7

7a. Second dorsal rays 6-7; male with vertical blue streaks along side of body Callionymus pusillus

7b. Second dorsal rays $8-10$; male without vertical blue streaks along side of body

8a. Second dorsal relatively low, without black blotches .. Callionymus lyra

8b. Second dorsal higher than second ray of first dorsal, with black blotches in rows. .. 9

9a. Second dorsal with horizontally arranged rows of dark blotches Callionymus maculatus

9 b. Second dorsal with obliquely or vertically arranged rows of dark blotches .. 10

10a. Antrorse tip at base of preopercular spine rudimentary or absent; second dorsal with 10 rays ..... Callionymus reticulatus

10b. Antrorse tip at base of preopercular spine well developed; second dorsal with 9 rays

.Callionymus fasciatus

\section{ACKNOWLEDGEMENTS}

We would like to thank the following persons for information, loan of specimens, or permission to examine 
specimens under their care (comparative materials): C.J. Ferraris Jr. (AMNH), D.A. Didier, W.F. Smith-Vaniz (ANSP), O. Crimmen, J. Maclaine (BMNH), D. Golani (HUJ), R. Robles (IEOV), J. Maigret (IFAN), J.-P. Gosse (IRSN), P. Pruvost (MNHN), M. Biscoito, G. E. Maul( $\dagger$ ) (MMF), G. Arbocco (MSNG), H. Ahnelt, R. Hacker $(\dagger)$ (NMW), T. Alpermann, W. Klausewitz, F. Krupp, H. Zetzsche (SMF), M. Goren, N. Stern (SMNHTAU), W. Vader (TMN), S. A. Fossaa (UBZM), S. Smith, J.T. Williams (USNM), H.-J. Paepke (ZMB), J. Nielsen (ZMUC). We are grateful to Ana Ventero and Sergio Ramírez-Amaro, both from the Centre Oceanogràfic de Balears, for their assistance in creating the figures.

The DRAGONSAL0914 survey was carried out within the project DRAGONSAL [Caracterización del Ecosistema Bentónico de la Plataforma costera del area comprendida entre sa Dragonera, cap de ses Salines y Cala Figuera (Mallorca)], co-funded by the Instituto Español de Oceanografía and the Balearic Islands Government. Sampling during the MEDITS_ES05_16 survey were funded by the AAEE7-2015 (Mejora de los studios de diversidad íctica en las Islas Baleares mediante técnicas morfológicas y moleculares, funded by the Conselleria d'Innovació, Recerca i Turisme, Balearic Islands Government) and the DEMBAGOL project (co-funded by the EU Data Collection Framework and the Instituto Español de Oceanografía).

\section{REFERENCES}

Albuquerque R.M. 1954-1956. Peixes de Portugal e ilhas adjacentes. Chaves para a sua determinação. [Fishes from Portugal and adjacent islands. Keys for their determination.] Portugaliae Acta Biologica Seria B 5: i-xvi + 1-1064, i-iii. [In Portuguese.]

Ballesteros E. 1994. The deep-water Peyssonnelia beds from the Balearic Islands (western Mediterranean). Marine Ecology 15 (3-4): 233-253. DOI: $10.1111 / \mathrm{j} .1439-0485.1994 . t b 00055 . \mathrm{x}$

Barberá C., Moranta J., Ordines F., Ramón M., de Mesa A., Díaz-Valdés M., Grau A.M., Massutí E. 2012. Biodiversity and habitat mapping of Menorca Channel (western Mediterranean): Implications for conservation. Biodiversity and Conservation 21 (3): 701-728. DOI: $\underline{10.1007 / \mathrm{s} 10531-011-0210-1}$

Bauchot M.-L., Daget J., Bauchot R. 1990. L'ichtyologie en France au début du XIXe siècle. L'Histoire naturelle des poissons de Cuvier et Valenciennes. Bulletin du Muséum nationale d'Histoire Naturelle, Paris, A (Zoologie) 4e série 12 (Suppl. 1): 1-142.

Boer P.jr. 1966. De rasterpitvis (Callionymus reticulatus C. \& V.), een nieuwe pitvis-soort voor onze fauna. [The chequered dragonet (Callionymus reticulatus $\mathrm{C}$. \& V.), a new dragonet species for our fauna.] De Levende Natuur, Amsterdam (7) 69 (11): 261-263. [In Dutch.]

Boer P. 1971. The occurrence of Callionymus reticulatus in the southern North Sea. Journal du Conseil International d'Exploration de la Mer 33 (3): 506-509. DOI: $10.1093 /$ icesjms/33.3.506
Chang H.-W. 1951. On Callionymus reticulatus C. \& $\mathrm{V}$. and its distribution in European seas. Journal of the Marine Biological Association of the United Kingdom 30 (2): 297-312.

DOI: $10.1017 / \mathrm{S} 0025315400012789$

Cuvier G., Valenciennes A. 1837a. Histoire naturelle des poissons. Tome douzième. Suite du livre quatorzième. Gobioïdes. Pp. 1-334. Levrault, Paris.

DOI: $\underline{10.5962 / \text { bhl.title. } 7339}$

Day F. 1881-1884. The fishes of Great Britain and Ireland. Vol. 1. Williams and Norgate, London and Edinburgh. Pp. I-CXII. 1-336. [Volume published 1880-1882; publication date of individual pages and plates see Hureau and Monod 1973: 44.] DOI: 10.5962/bhl. title.58639

de Buen F. 1935. Fauna ictiológica. Catálogo de los peces ibéricos: de la planicie continental, aguas dulces, pelágicos y de los abismos próximos. Segunda parte. Notas y Resumenes, Instituto Español de Oceanografía, Serie 289 (2): 91-249, pls. 21-53.

da Cunha P.L., Antunes M.M. 2012. Note on the occurrence of Callionymidae at the coast of Estoril, Portugal. Cybium 36 (3): 489-492.

Demir N. 1972. The abundance and distribution of the eggs and larvae of some teleost fishes off Plymouth in 1969 and 1970. II. The postlarvae of Callionymus. Journal of the Marine Biological Association of the United Kingdom 52 (4): 997-1010. DOI: $10.1017 / \mathrm{S} 0025315400040716$

Eschmeyer W.N., Fricke R., Van der Laan R. (ed.) 2017. Catalog of fishes. California Academy of Sciences, San Francisco. [Accessed on 22 February 2017.] http://research.calacademy.org/research/Ichthyology/ Catalog/fishcatmain.asp

Farias C., Ordines F., García-Ruiz C., Fricke R. 2016. Protogrammus alboranensis n. sp. (Teleostei: Callionymidae), a new species of dragonet from the Alboran Sea, western Mediterranean Sea. Scientia Marina 80 (1): 1-6. DOI: $10.3989 /$ scimar.04340.13A

Fricke R. 1982. Nominal genera and species of dragonets (Teleostei: Callionymidae, Draconettidae). Annali del Museo Civico di Storia Naturale Genova 84: 53-92.

Fricke R. 1983a. Revision of the Indo-Pacific genera and species of the dragonet family Callionymidae (Teleostei). Theses Zoologicæ. Vol. 3. Verlag von J. Cramer, Braunschweig, Germany.

Fricke R. 1983b. A method of counting caudal fin rays of actinopterygian fishes. Braunschweiger Naturkundliche Schriften 1 (4): 729-733.

Fricke R. 1987. Callionymidae. Pp. 1002-1006. In: Fischer W., Schneider M., Bauchot M.-L. (eds.) Méditerranée et Mer Noire. Zone du Pêche 37. Révision 1. Vol. 2. Vertébrés. Rome (FAO).

Fricke R. 2002. Annotated checklist of the dragonet families Callionymidae and Draconettidae (Teleostei: Callionymoidei), with comments on callionymid fish classification. Stuttgarter Beiträge zur Naturkunde, Serie A (Biologie) 645: 1-103. 
Fricke R. 2016. Suborder Callionymoidei. Callionymidae. Dragonets. Pp. 2810-2824. In: Carpenter K.E., de Angelis N. (eds.) The living marine resources of the eastern Central Atlantic. Vol. 4. Bony fishes part 2 (Perciformes to Tetraodontiformes) and sea turtles. Rome (FAO).

Fricke R. (ed.) 2017. References in the Catalog of fishes. California Academy of Sciences, San Francisco. [Accessed on 22 February 2017.] http://research. calacademy.org/research/Ichthyology/Catalog/ fishcatmain.asp

Fricke R., Eschmeyer W.N. 2017. Guide to fish collections in the Catalog of fishes. California Academy of Sciences, San Francisco. [Accessed on 22 February 2017.] http://research.calacademy.org/ research/Ichthyology/Catalog/collections.asp

Fröiland Ö., Greve L. 1976. Callionymus reticulatus (Pisces, Callionymidae) from western Norway. Sarsia 62 (1): 1-3.

DOI: $10.1080 / 00364827.1976 .10411308$

Gökoğlu M., Özvarol Y., Fricke R. 2014. Synchiropus sechellensis Regan, 1908 (Teleostei: Callionymidae), a new Lessepsian migrant in the Mediterranean Sea. Mediterranean Marine Science 15 (2): 440-442. DOI: $10.12681 / \mathrm{mms} .906$

Hubbs C.L., Lagler K.F. 1947. Fishes of the Great Lakes region. Bulletin, Cranbrook Institute of Science No. 26. Bloomfield Hills, MI, USA.

Hureau J.-C., Monod T. 1973. Checklist of the fishes of the northeastern Atlantic and of the Mediterranean. Vol. 2. CLOFNAM. UNESCO, Paris.

Iglesias J. 1981. Spatial and temporal changes in the demersal fish community of the Ria de Arosa (NW Spain). Marine Biology 65 (2): 199-208. DOI: $\underline{10.1007 / \mathrm{BF} 00397086}$

le Mao P. 2009. Inventaire de la biodiversité marine dans le golfe normano-breton; Agnathes, Condrichtyens et Osteichtyens. Rapport. IFREMER RST.LER/FBN09-14.

Moreau É. 1881. Histoire naturelle des poissons de la France. Tome deuxième. Pp. 1-572. G. Masson, Paris. DOI: $10.5962 /$ bhl.title. 12541

Nakabo T., Hartel K.E. 1999. Foetorepus goodenbeani: A new species of dragonet (Teleostei: Callionymidae) from the western North Atlantic Ocean. Copeia 1999 (1): 114-121.

Neudecker T., Damm U. 2004. Recognition of a third callionymid species, Callionymus reticulatus Valenciennes 1837 (reticulated dragonet), in the southeastern North Sea. Journal of Applied Ichthyology 20 (3): 204-210. DOI: $10.1111 / \mathrm{j} .1439-0426.2004 .00515 . \mathrm{x}$

Nobre A. 1935. Fauna marinha de Portugal; I Vertebrados (Mamiferos, Reptis e Peixes). [Marine fauna of Portugal; I Vertebrates (mammals, reptiles, and fishes).] Porto, Portugal.
Ordines F., Jordà G., Quetglas A., Flexas M., Moranta J., Massutí E. 2011. Connections between hydrodynamics, benthic landscape and associated fauna in the Balearic Islands, western Mediterranean. Continental Shelf Research 31 (17): 1835-1844. DOI: $10.1016 /$ j.csr.2011.08.007

Ordines F., Massutí E. 2009. Relationships between macroepibenthic communities and fish on the shelf grounds of the western Mediterranean. Aquatic Conservation Marine and Freshwater Ecosystems 19 (4): 370-383. DOI: $\underline{10.1002 / \text { aqc. } 969}$

Quéro J.-C., Spitz J., Vayne J.-J. 2003. Observations ichtyologiques effectuées en 2002. Annales de la Société des Sciences Naturelles de la CharanteMaritime 9 (3): 275-279.

Quéro J.-C., Spitz J., Vayne J.-J., Auby I., de Casamajor M.N., Leaute J.-P., Marie F., Monhurel L., Quinquis J. 2009. Observations ichtyologiques effectuées en 2008. Annales de la Société des Sciences Naturelles de la Charante-Maritime 9 (9): 932-940.

Ryland J.S. 1969. Some shore fishes from Galway Bay. Irish Naturalist's Journal 16 (5): 127-131.

Santos R.S., Porteiro F.M., Barreiros J.P. 1997. Marine fishes of the Azores: An annotated checklist and bibliography. Arquipélago, Life and Marine Sciences, Supplement 1: 1-242.

Seyhan D., Irmak E., Fricke R. 2017. Diplogrammus randalli (Pisces: Callionymidae), a new Lessepsian migrant recorded from the Mediterranean Sea. Mediterranean Marine Science 18 (1): 1-3. DOI: $10.12681 / \mathrm{mms} .1948$

Wheeler A.C. 1961 [Published 1962]. Callionymus reticulatus C. \& V. as a North Sea fish. Annals and Magazine of Natural History, Series 134 (48): 753-754. DOI: $\underline{10.1080 / 00222936108651203}$

Wheeler A.C. 1969. The fishes of the British isles and north-west Europe. Michigan State University Press, East Lansing, MI, USA.

Wheeler A.C. 1973. Callionymidae. Pp. 516-518. In: Hureau J.-C., Monod T. (eds.) Checklist of the fishes of the north-eastern Atlantic and the Mediterranean. Vol. 1. CLOFNAM I. UNESCO Paris.

Wheeler A.C., Blacker R.W., Pirie S.F. 1975. Rare and little-known fishes in British seas in 1970 and 1971. Journal of Fish Biology 7 (2): 183-201. DOI: $10.1111 / \mathrm{j} .1095-8649.1975 . t b 04589 . \mathrm{x}$

Whitehead P.J.P., Bauchot M.-L., Hureau J.-C., Nielsen J., Tortonese E. 1986. Fishes of the northeastern Atlantic and the Mediterranean. Vol. 3. UNESCO, Paris.

Zander C.D. 1979. On the biology and food of smallsized fish from the North and Baltic Sea area. I. Investigations on Pomatoschistus pictus (Malm) (Gobiidae) from Helgoland. Zoologischer Anzeiger 202 (5-6): 413-424.

Received: 17 October 2016 Accepted: 25 April 2017 Published electronically: 30 June 2017 